\title{
Hubungan Pemberian ASI Eksklusif dengan Angka Kejadian Diare Akut pada Bayi Usia 0-1 Tahun di Puskesmas Kuranji Kota Padang
}

\author{
Eka Putri Rahmadhani, Gustina Lubis, Edison
}

\begin{abstract}
Abstrak
Pemberian ASI eksklusif merupakan salah satu upaya untuk mencapai tumbuh kembang optimal dan terlindungi dari penyakit seperti diare. Tujuan penelitian ini adalah untuk mengetahui hubungan pemberian ASI eksklusif dengan angka kejadian diare akut pada bayi usia 0-1 tahun di Puskesmas Kuranji Kota Padang. Penelitian ini dilaksanakan secara observasional dengan pendekatan cross sectional. Sampel penelitian ini adalah bayi usia 0-1 tahun yang berkunjung ke posyandu di wilayah kerja Puskesmas Kuranji Kota Padang dengan menggunakan simple random sampling. Jumlah bayi dengan kelompok usia 0-5 bulan 29 hari sebanyak 69 orang (51,1\%) dan usia 6-12 bulan sebanyak 66 orang (48,9\%). Dari hasil penelitian didapatkan bayi usia 0-5 bulan 29 hari yang masih mendapat ASI saja sebanyak 41 bayi $(30,4 \%)$ dan yang sudah mendapat campuran lain selain ASI sebanyak 28 bayi $(20,7 \%)$. Jumlah bayi usia $6-12$ bulan dengan ASI eksklusif sebanyak 34 bayi $(25,2 \%)$ dan 32 bayi lainnya (23,7\%) non ASI eksklusif. Sebanyak 57 bayi (42,2\%) pernah diare dan 78 bayi lainnya (57,8\%) tidak pernah. Analisis chi square mendapatkan $p=0,001$ dan hasil ini signifikan $(p<0,5)$. Pemberian ASI eksklusif selama 6 bulan harus ditingkatkan karena mempunyai hubungan dengan angka kejadian diare akut.
\end{abstract}

Kata kunci: Bayi, ASI Exclusif, diare

\begin{abstract}
Exclusive breastfeeding is an effort to achieve optimal growth and development and can be protected from diarrhea. The purpose of this study was to determine the relationship of exclusive breastfeeding with the incidence of acute diarrhea in infants aged 0-1 years in the Kuranji Public Health Center Padang. This study conducted a cross sectional observational study. The sample was a baby aged 0-1 years who visited posyandu in the Kuranji Public Health Center working area using simple random sampling. The result showed 41 infants (30.4\%) aged 0-5 months 29 days which is still breastfed only and other than breast milk were 28 infants (20.7\%). Number of 6-12 months infants are exclusively breastfed as many as 34 babies (25.2\%) while the other 32 babies (23.7\%) were not exclusively breastfed. A total of 57 infants (42.2\%) had suffered from diarrhea and the other 78 infants (57.8\%) had never. Chi square analysis got $p=0.001$ and the results are significant $(p<0.5)$. Exclusive breastfeeding for 6 months should be improved because it has relation with diarrhea.
\end{abstract}

Keywords:Baby, Exclusive breastfeeding, diarrhea

Affiliasi penulis : Eka Putri Rahmadhani

Korespondensi : Fakultas Kedokteran Universitas Andalas, email : poetry.ramadan@gmail.com, Telp/Hp : 085365348203

\section{PENDAHULUAN}

Diare merupakan salah satu penyebab utama morbiditas dan mortalitas pada anak di negara berkembang. Anak usia 0-3 tahun rata-rata mengalami tiga kali diare pertahun. Menurut WHO (2009) diare adalah suatu keadaan buang air besar (BAB) dengan konsistensi lembek hingga cair dan frekuensi lebih dari tiga kali sehari. Diare akut berlangsung selama 3-7 hari, sedangkan diare persisten terjadi selama $\geq 14$ hari. Secara klinis penyebab diare terbagi menjadi enam kelompok, yaitu infeksi, malabsorbsi, alergi, keracunan makanan, imunodefisiensi dan penyebab lainnya ,misal: gangguan fungsional dan malnutrisi.

Berdasarkan Riset Kesehatan Dasar (Riskesdas) tahun 2007, didapatkan bahwa penyebab kematian bayi (usia 29 hari-11 bulan) yang terbanyak adalah diare $(31,4 \%)$ dan pneumonia $(23,8 \%)$. Hasil Survei Morbiditas Diare dari tahun 2000 s.d. 2010 didapatkan angka kesakitan diare balita Tahun 20002010 tidak menunjukkan pola kenaikan maupun pola penurunan (berfluktuasi). Pada tahun 2000 angka kesakitan balita 1.278 per 1000 , sedikit menurun di tahun 2003 (1.100 per 1000), agak meningkat pada tahun 2006 (1.330 per 1000), dan di tahun 2010 angka morbiditas kembali menurun (1.310 per 1000). Dilihat dari distribusi umur balita penderita diare di tahun 2010 didapatkan proporsi terbesar adalah kelompok umur $6-11$ bulan yaitu sebesar $21,65 \%$, lalu kelompok umur 12-17 bulan sebesar $14,43 \%$, kelompok umur 24-29 bulan sebesar 12,37\%, sedangkan proporsi terkecil pada kelompok umur 54 59 bulan yaitu $2,06 \%$.

Depkes RI didukung oleh Ikatan Dokter Indonesia (IDAI) telah mencanangkan panduan terbaru tatalaksana diare pada anak, yaitu Lima Langkah Tuntaskan Diare (LINTAS DIARE), yang terdiri dari: pemberian cairan, pemberian zink selama 10 hari berturut-turut, meneruskan pemberian ASI dan makanan, pemberian antibiotik secara selektif dan pemberian nasihat pada ibu/keluarga pasien. ${ }^{3}$

Pada waktu lahir sampai beberapa bulan sesudahnya, bayi belum dapat membentuk kekebalan sendiri secara sempurna. ASI memberikan zat-zat kekebalan yang belum dapat dibuat oleh bayi tersebut, sehingga bayi yang minum ASI lebih jarang sakit, terutama pada awal dari kehidupannya. Komponen zat anti infeksi yang banyak dalam ASI akan melindungi bayi dari berbagai macam infeksi, baik yang disebabkan oleh bakteri, virus, dan antigen lainnya. 
Pada tahun 2001, setelah melakukan telaah artikel secara sistemik dan berkonsultasi dengan para pakar, WHO merevisi rekomendasi ASI eksklusif dari 4-6 bulan menjadi 6 bulan. Hasil dari artikel tersebut menyimpulkan bahwa bayi yang disusui secara eksklusif sampai 6 bulan umumnya lebih sedikit menderita penyakit gastrointestinal dan lebih sedikit mengalami gangguan pertumbuhan. Definisi ASI eksklusif bermacam-macam tetapi definisi yang sering digunakan adalah definisi WHO yang menyebutkan ASI eksklusif adalah pemberian hanya ASI saja tanpa cairan atau makanan padat apapun kecuali vitamin, mineral, atau obat dalam bentuk tetes atau sirup sampai usia 6 bulan. ${ }^{5}$

Praktek pemberian ASI dinegara berkembang telah berhasil menyelamatkan sekitar 1,5 juta bayi per tahun dari kematian dan kesakitan. Atas dasar tersebut WHO merekomendasikan untuk pemberian ASI eksklusif sampai bayi 6 bulan. Setiap tahunnya lebih dari 25.000 bayi di Indonesia dan 1,3 juta bayi di dunia dapat diselamatkan dari kematian dengan pemberian ASI eksklusif. $^{6}$

Tanggal 1 Maret 2012 dikelurkanlah PP Nomor 33 Tahun 2012 tentang Pemberian Air Susu Ibu (ASI) Eksklusif yang ditandatangani oleh Presiden Susilo Bambang Yudhoyono. Peraturan ini melaksanakan ketentuan pasal 129 ayat (2) UU Nomor 36 Tahun 2009 tentang kesehatan. Dalam rangka melindungi, mendukung, dan mempromosikan pemberian ASI eksklusif perlu dilakukan upaya untuk meningkatkan dukungan dari pemerintah, pemerintah daerah, fasilitas pelayanan kesehatan dan tenaga kesehatan, masyarakat serta keluarga agar ibu dapat memberikan ASI eksklusif pada bayi.

Secara nasional cakupan pemberian ASI eksklusif di Indonesia berfluktuasi selama 3 tahun terakhir. Cakupan pemberian ASI eksklusif pada bayi 0-5 bulan turun dari $62,2 \%$ tahun 2007 menjadi 56,2\% pada tahun 2008, namun meningkat lagi pada tahun 2009 menjadi $61,3 \%$. Sedangkan cakupan pemberian ASI eksklusif pada bayi sampai 6 bulan turun dari $28,6 \%$ pada tahun 2007 menjadi $24,3 \%$ pada tahun 2008 dan naik lagi menjadi 34,3\% pada tahun 2009 . Alasan yang menjadi penyebab kegagalan praktek ASI eksklusif bermacam-macam seperti budaya memberikan makanan pralaktal, memberikan tambahan susu formula karena ASI tidak keluar, menghentikan pemberian ASI karena bayi atau ibu sakit, ibu harus bekerja, dan ibu ingin mencoba susu formula. ${ }^{8}$

Berdasarkan data dari Dinas Kesehatan Kota Padang tahun 2011 didapatkan data diare pada bayi 0-1 tahun di Puskesmas Kuranji adalah sebanyak 97 kasus yaitu sebanyak $9.09 \%$ dari seluruh kasus diare di puskesmas-puskesmas kota Padang. Angka ini termasuk tinggi dibandingkan angka kejadian diare di puskesmas lainnya di Kota Padang. Tujuan penelitian ini adalah untuk melihat hubungan pemberian ASI eksklusif tersebut terhadap kejadian diare akut pada bayi 0-1 tahun di Puskesmas Kuranji, Kota Padang.

\section{METODE PENELITIAN}

Penelitian ini merupakan studi potong lintang (cross sectional) untuk mengetahui adanya hubungan pemberian ASI eksklusif dengan kejadian diare akut pada bayi 0-1 tahun. Metode potong lintang ini adalah metode yang meneliti hubungan antara variabel independen (faktor risiko) dengan variabel dependen (efek) dengan melakukan pengukuran sesaat. ${ }^{9}$
Sampel penelitian diambil dari populasi ibu yang mempunyai bayi umur 0-1 tahun yang berkunjung ke posyandu di daerah kerja Puskesmas Kuranji, Kota Padang dengan metode simple random sampling. Menurut Suyatno, ${ }^{10}$ menentukan besarnya sampel pada penelitian cross sectional yang telah diketahui jumlah populasinya dapat digunakan rumus:

$$
\mathrm{n}=\frac{Z^{2} \cdot 1-\alpha / 2 \mathrm{p}(1-\mathrm{p}) \mathrm{N}}{d^{2}(\mathrm{~N}-1)+Z^{2} \cdot 1-a / 2 \mathrm{p}(1-\mathrm{p})}
$$

Didapatkanlah jumlah sampel pada penelitian ini sebanyak 135 bayi. Kriteria inklusi sampel penelitian adalah bayi berumur 0-1 tahun, berkunjung ke posyandu wilayah kerja Puskesmas Kuranji, Kota Padang, serta ibu dari bayi yang bersedia menjadi responden. Kriteria eksklusi antara lain bayi yang sakit berat, menderita diare kronis, serta bayi berat lahir rendah (BBLR) dan riwayat premature (kehamilan $<37$ minggu).

Variabel dependen dari penelitian ini adalah kejadian diare akut, yaitu suatu penyakit yang ditandai dengan bertambahnya frekuensi defekasi lebih dari 4 kali/hari disertai konsistensi tinja menjadi cair, dengan/tanpa lendir atau darah dan berlangsung kurang dari 14 hari. $^{11}$ Sedangkan variabel independen adalah pemberian ASI eksklusif, yaitu pemberian ASI saja tanpa tambahan cairan lainnya, seperti susu formula, madu, air teh, air putih, dan tanpa makanan tambahan padat seperti pisang, pepaya, bubur susu, biskuit, bubur nasi, dan tim, sampai usia 6 bulan. ${ }^{12}$ Kedua variabel diukur menggunakan kuesioner dengan wawancara terpimpin sehingga didapatkan skala ukurnya nominal. Penelitian ini dilakukan di 23 posyandu wilayah kerja Puskesmas Kuranji, Kota Padang. Waktu penelitian sudah dilaksanakan bulan November tahun 2011 - September tahun 2012.

Langkah-langkah pengolahan data adalah pemeriksaan kelengkapan dan kejelasan data, pemberian kode pada setiap data variabel, memasukkan data dalam program SPSS (Statistical Program for Social Science), serta pemeriksaan kembali untuk memastikan bahwa data tersebut telah bersih dari kesalahan. Analisis data terdiri dari analisis univariat dan bivariat ${ }^{9}$. Pada analisis bivariat dicari hubungan antara dua variabel dengan menggunakan rumus chi square $\left(\mathrm{X}^{2}\right)$ dan kekuatan hubungan dua variabel dengan rumus koefisien kontingensi $(C) .^{13}$ Adapun rumusnya:

$$
\mathrm{C}=\sqrt{\frac{x^{2}}{x^{2}+N}} \quad \text { dan } \quad X^{2}=\Sigma \frac{\left(O_{i j}-E_{i j}\right)^{2}}{E_{i j}}
$$

\section{HASIL}

a. Karakteristik Responden

Tabel 1: Distribusi frekuensi bayi berdasarkan kelompok usia di Puskesmas Kuranji Kota Padang.

\begin{tabular}{ccc}
\hline Usia Bayi & Frekuensi & $\begin{array}{c}\text { Persentase } \\
(\%)\end{array}$ \\
\hline 0 - 5 bulan 29 hari & 69 & 51,1 \\
6 - 12 bulan & 66 & 48,9 \\
\hline jumlah & 135 & 100 \\
\hline
\end{tabular}

Bayi berusia < 6 bulan lebih banyak dibandingkan bayi > 6 bulan. Pembagian kelompok umur ini dimaksudkan untuk mendapatkan jumlah bayi yang mendapat 
ASI saja dengan bayi yang mendapat ASI eksklusif karena pengertian pemberian ASI eksklusif dilakukan selama 6 bulan.

\section{b. Pemberian ASI Eksklusif}

Tabel 2: Distribusi frekuensi bayi usia $6-12$ bulan berdasarkan pemberian ASI eksklusif di Puskesmas Kuranji Kota Padang.

\begin{tabular}{ccc}
\hline $\begin{array}{c}\text { ASI } \\
\text { Eksklusif }\end{array}$ & $\begin{array}{c}\text { Frekuensi } \\
\text { (f) }\end{array}$ & $\begin{array}{c}\text { Persentase } \\
\text { (\%) }\end{array}$ \\
\hline Ya & 34 & 51,5 \\
Tidak & 32 & 48,5 \\
\hline Total & 66 & 100 \\
\hline
\end{tabular}

\section{c. Pemberian ASI Saja}

Tabel 3: Distribusi frekuensi bayi usia 0 - 5 bulan 29 hari yang mendapat ASI saja dari lahir sampai diteliti di Puskesmas Kuranji Kota Padang.

\begin{tabular}{ccc}
\hline ASI Saja & $\begin{array}{c}\text { Frekuensi } \\
\text { (f) }\end{array}$ & $\begin{array}{c}\text { Persentase } \\
\text { (\%) }\end{array}$ \\
\hline Ya & 41 & 59,4 \\
Tidak & 28 & 40,6 \\
\hline Total & 69 & 100 \\
\hline
\end{tabular}

\section{d. Alasan ibu tidak memberikan AS} eksklusif ataupun ASI saja pada bayi

Tabel 4: Distribusi frekuensi alasan ibu tidak memberikan ASI eksklusif ataupun ASI saja pada bayi di Puskesmas Kuranji Kota Padang.

\begin{tabular}{lcc}
\hline \multicolumn{1}{c}{ Alasan Ibu } & $\begin{array}{c}\text { Frekuensi } \\
\text { (f) }\end{array}$ & $\begin{array}{c}\text { Persentase } \\
(\%)\end{array}$ \\
\hline ASI kurang & 31 & 32,3 \\
Bayi terlihat belum & 41 & 42,7 \\
kenyang dengan ASI & & \\
saja & & \\
Ibu sakit & 9 & 9,4 \\
Bayi sakit & 4 & 4,2 \\
lbu bekerja & 10 & 10,4 \\
Lain-lain & 1 & 1,1 \\
\hline \multicolumn{1}{c}{ Total } & 96 & 100 \\
\hline \multicolumn{2}{c}{} \\
\hline
\end{tabular}

Tabel 4 menunjukkan bahwa keadaan bayi yang belum terlihat kenyang dengan ASI saja merupakan alasan terbanyak dari 96 alasan ibu tidak memberikan ASI eksklusif ataupun ASI saja pada bayi. Kuesioner penelitian ini memperbolehkan ibu untuk memilih lebih dari satu alasan tidak memberikan ASI eksklusif ataupun ASI saja pada bayinya.

\section{e. Riwayat Diare Akut}

Tabel 5: Distribusi frekuensi bayi usia $6-12$ bulan berdasarkan riwayat diare akut $d$ Puskesmas Kuranji Kota Padang.

\begin{tabular}{ccc}
\hline $\begin{array}{c}\text { Diare } \\
\text { Akut }\end{array}$ & $\begin{array}{c}\text { Frekuensi } \\
\text { (f) }\end{array}$ & $\begin{array}{c}\text { Persentase } \\
\text { (\%) }\end{array}$ \\
\hline Ya & 34 & 51,5 \\
Tidak & 32 & 48,5 \\
\hline Total & 66 & 100 \\
\hline
\end{tabular}

Tabel 6: Distribusi frekuensi bayi usia $0-5$ bulan 29 hari berdasarkan riwayat diare akut di Puskesmas Kuranji Kota Padang.

\begin{tabular}{ccc}
\hline $\begin{array}{c}\text { Diare } \\
\text { Akut }\end{array}$ & Frekuensi (f) & $\begin{array}{c}\text { Persentase } \\
\text { (\%) }\end{array}$ \\
\hline Ya & 22 & 31,9 \\
Tidak & 47 & 68,1 \\
\hline Total & 69 & 100 \\
\hline
\end{tabular}

\section{f. Hasil Penelitian Bivariat}

Tabel 7: Hubungan Pemberian ASI Eksklusif dengan Angka Kejadian Diare Akut Pada Bayi Usia 6-12 Bulan di Puskesmas Kuranji Kota Padang.

\begin{tabular}{ccccc}
\hline \multirow{2}{*}{$\begin{array}{c}\text { ASI } \\
\text { Eksklusif }\end{array}$} & \multicolumn{2}{c}{ Diare Akut } & Total & P value \\
\cline { 2 - 3 } & Tidak & Ya & & \\
\cline { 1 - 3 } Ya & $\begin{array}{c}25 \\
(73,5 \%)\end{array}$ & $\begin{array}{c}9 \\
(26,5 \%)\end{array}$ & $\begin{array}{c}34 \\
(100 \%)\end{array}$ & \\
\cline { 1 - 2 } Tidak & $6(18,7 \%)$ & $\begin{array}{c}26 \\
(74,3 \%)\end{array}$ & $\begin{array}{c}32 \\
(100 \%)\end{array}$ & 0,001 \\
\cline { 1 - 2 } Total & $31(47 \%)$ & $\begin{array}{c}35 \\
(53 \%)\end{array}$ & $\begin{array}{c}66 \\
(100 \%)\end{array}$ & \\
\hline
\end{tabular}

Tabel 7 menunjukkan diare akut lebih sering pada bayi yang tidak mendapat ASI eksklusif $(74,3 \%)$ dibandingkan dengan bayi yang mendapat ASI eksklusif (26,5\%) dengan uji statistik sangat bermakna $(p<0,5)$. Nilai $X^{2}$ dari tabel kontingensi adalah 19,9 maka nilai C (koefisien kontingensi) yang didapatkan adalah $0,5 \quad(\mathrm{C} \neq 0)$. Hal ini menunjukkan terdapat hubungan antara pemberian ASI eksklusif dengan angka kejadian diare akut pada bayi usia 0-1 tahun di Puskesmas Kuranji Kota Padang. Menurut Effendi dan Singarimbun dalam bukunya yang berjudul Metode Penelitian Survai (2011), nilai C yang berada antara 0,5- 0,75 mengartikan bahwa kekuatan hubungan antara dua variabel bersifat sedang. ${ }^{13}$

\section{PEMBAHASAN}

Berdasarkan data kepustakaan mengenai angka kejadian diare pada bayi, Riskesdas (Riset Kesehatan Dasar) tahun 2007 menyatakan bahwa bayi berusia 29 hari-11 bulan adalah kelompok umur yang paling banyak terjangkit diare $(31,4 \%)$. Satu dari beberapa penyebabnya adalah tidak memberikan ASI eksklusif sehingga bayi lebih rentan terjangkit penyakit yang salah satunya adalah diare. Penelitian ini dilakukan di 23 posyandu yang berada di wilayah kerja Puskesmas Kuranji Kota Padang pada tahun 2012. Berdasarkan penelitian didapatkan 69 bayi $(51,1 \%)$ berusia $0-5$ bulan 29 hari dan 66 bayi lainnya (48,8\%) berusia $6-12$ bulan 
Menurut Fikawati dan Syafiq, ${ }^{5}$ WHO menyatakan ASI eksklusif adalah pemberian ASI saja tanpa tambahan cairan atau makanan padat apapu kecuali vitamin, mineral, atau obat dalam bentuk tetes ataupun sirup sampai usia 6 bulan. Berdasarkan pengertian tersebut, penelitian ini membagi dua kelompok umur bayi yang menjadi sampel, yaitu bayi yang mendapat ASI eksklusif pada kelompok usia 612 bulan dan bayi yang mendapat ASI saja pada kelompok usia 0-5 bulan 29 hari. Jumlah bayi yang mendapat ASI eksklusif lebih banyak yaitu 34 bayi $(25,2 \%)$ dibandingkan yang tidak mendapat ASI eksklusif yaitu 32 bayi $(23,7 \%)$. Jumlah bayi yang mendapat ASI saja 41 bayi $(30,4 \%)$ dan 28 bayi $(20,7 \%)$ lainnya sudah diberikan campuran makanan atau minuman lainnya selain ASI. Alasan ibu tidak memberikan ASI eksklusif ataupun sudah mencampuri ASI dengan makanan atau minuman lainnya sebelum berusia 6 bulan adalah keadaan bayi yang belum kenyang dengan ASI saja $(42,7 \%)$, ASI kurang $(32,3 \%)$, ibu bekerja $(10,4 \%)$, ibu sakit $(9,4 \%)$, bayi sakit $(4,2 \%)$, dan lain-lain $(1,1 \%)$.

Menurut $\mathrm{WHO}^{1}$ diare adalah suatu keadaan buang air besar (BAB) dengan konsistensi lembek hingga cair dan frekuensi lebih dari tiga kali sehari. Diare akut berlangsung 3-7 hari. Jumlah bayi yang pernah menderita diare pada kelompok usia 6-12 bulan sebanyak 34 bayi (51,5\%). Angka ini lebih banyak dibandingkan jumlah bayi yang tidak pernah diare, yaitu 32 bayi (48,5\%). Jumlah bayi yang pernah menderita diare pada kelompok usia 0-5 bulan 29 hari sebanyak 22 bayi $(31,9 \%)$ dan angka ini lebih sedikit dibandingkan bayi yang tidak pernah diare, yaitu 47 bayi $(68,1 \%)$.

Tabel hubungan pemberian ASI eksklusif dengan angka kejadian diare akut pada bayi usia 6-12 bulan di Puskesmas Kuranji Kota Padang menunjukkan bahwa kejadian diare pada bayi yang mendapat ASI eksklusif sebanyak 9 bayi $(26,5 \%)$ dan angka ini lebih rendah dibandingkan kejadian diare pada bayi tidak mendapat ASI eksklusif, yaitu 26 bayi $(74,3 \%)$. Jumlah bayi yang tidak pernah diare lebih tinggi pada kelompok bayi yang mendapat ASI eksklusif, yaitu 25 bayi (73,58\%) dibandingkan bayi yang tidak mendapat ASI eksklusif, yaitu 6 bayi $(18,7 \%)$. Berdasarkan data tersebut didapatkan hasil bahwa kejadian diare pada bayi yang tidak mendapat ASI eksklusif lebih tinggi dibandingkan dengan bayi yang mendapat ASI eksklusif. Hasil ini menunjukkan bahwa bayi yang tidak mendapat ASI eksklusif lebih rentan terhadap diare.

Hegar dan Sahetapy ${ }^{14}$ menyebutkan bahwa salah satu kandungan unik ASI adalah oligosakarida yang akan menciptakan suasana asam dalam saluran cerna. Suasana asam ini berfungsi sebagai sinyal untuk pertahanan saluran cerna, yaitu SIgA (Secretory Imunnoglobulin $A$ ) yang juga terdapat dalam ASI itu sendiri. SlgA dapat mengikat mikroba patogen, mencegah perlekatannya pada sel enterosit di usus dan mencegah reaksi imun yang bersifat inflamasi sehingga diare tidak terjadi. ${ }^{15} \mathrm{Hal}$ ini sesuai dengan penelitian Lely $^{16}$ yang mencari peran ASI eksklusif yang mengandung SIgA terhadap risiko diare akut. Penelitian tersebut menggambarkan kejadian diare akut pada bayi dengan ASI eksklusif $34,8 \%$. Angka tersebut lebih rendah dibandingkan kejadian diare akut pada bayi tanpa ASI eksklusif, yaitu $65,2 \%$.
Menurut Suradi ${ }^{17}$ bayi yang mendapat $\mathrm{ASI}$ lebih jarang terkena diare karena adanya zat protektif saluran cerna seperti Lactobacillus bifidus, laktoferin, lisozim, SlgA, faktor alergi, serta limfosit T dan B. Zat protektif ini berfungsi sebagai daya tahan tubuh imunologik terhadap zat asing yang masuk dalam tubuh. Penelitian oleh Lamberti et al $^{18}$ yang dilakukan di negara-negara berkembang menunjukkan perbandingan risiko diare pada bayi yang tidak mendapat ASI eksklusif lebih tinggi $(2,65)$ dibanding yang mendapatkan ASI secara eksklusif $(1,26)$.

Tabel hubungan pemberian ASI eksklusif dengan angka kejadian diare akut pada bayi usia 6-12 bulan di Puskesmas Kuranji Kota Padang juga menunjukkan $p$ value sebesar 0,001 dan angka ini bersifat signifikan $(p<0,5)$. Nilai ini menunjukkan adanya hubungan antara pemberian ASI eksklusif dengan angka kejadian diare akut. Hubungan yang sama juga telah dibuktikan oleh Wijayanti ${ }^{19}$ dalam penelitiannya yang membandingkan kejadian diare bayi 0 - 6 bulan dengan ASI eksklusif dan bayi tanpa ASI eksklusif di Puskesmas Gilingan Kecamatan Banjarsari, Surakarta. Hasil penelitian menunjukkan angka $p=0,000$ yang bersifat signifikan dan bermakna $(p<0,5)$

Nilai cotingency coeffisient (rumus C) yang menyatakan kekuatan atau keeratan hubungan antarvariabel didapatkan sebesar $0,5(C \neq 0)$. Nilai ini mengartikan adanya hubungan antara variabel diare akut dengan pemberian ASI eksklusif yang bersifat sedang. Kekuatan bersifat sedang ini menyatakan bahwa penyebab terjadinya diare tidak hanya dipengaruhi oleh ASI tetapi disebabkan juga oleh beberapa faktor risiko seperti pengaruh sosial ekonomi, budaya, kepadatan penduduk, dan lain-lain. Dalam penelitian ini terdapat beberapa kelemahan seperti berlebihnya waktu yang dibutuhkan untuk meneliti dibandingkan perkiraan awal yaitu Mei - Juni 2012 menjadi Mei - September 2012. Puskesmas Kuranji memiliki 23 posyandu yang tersebar di Kelurahan Kalumbuk dan Kelurahan Korong Gadang. Jadwal pelaksanaan posyandu ini dimulai dari hari senin sampai kamis setiap pukul 9.00-12.00 WIB dalam tiga minggu pertama setiap bulan. Setiap hari posyandu diadakan didua tempat yang berbeda secara bersamaan. Peneliti pun tidak dapat mengunjungi setiap posyandu dalam waktu bersamaan.

\section{KESIMPULAN}

Setelah melakukan penelitian di 23 posyandu wilayah kerja Puskesmas Kuranji Kota padang didapatkan kesimpulan bahwa lebih banyak bayi yang mendapat ASI eksklusif dibandingkan yang tidak. Selain itu jumlah bayi yang pernah menderita diare lebih sedikit dibandingkan yang tidak pernah. Dari uji statistik didapatkan pula nilai yang signifikan pada hubungan pemberian ASI eksklusif dengan angka kejadian diare akut pada bayi usia 0-1 tahun di Puskesmas Kuranji Kota Padang.

\section{Daftar Pustaka}

1. WHO. Diarrhoeal disease. 2009 (diunduh 25 Februari 2012). Tersedia dari URL: HYPERLINK http://www.who.int/mediacentre/facsheets/fs3 30/en/

2. Kemenkes RI. Situasi Diare di Indonesia. 2011 (diunduh 24 februari 2012). Tersedia 
dari

URL:

HYPERLINK

http://www.depkes.go.id/downloads/Buletin\% 20Diare Final(1).pdf

3. Cheung, Pik-To dan Pak-Chung Ho. Journal of Paedetrics, Obstetrics \& Gynaecology. 2011. Volume 37,nomor 4:146.

4. Suraatmaja,Sudaryat. Gastroenterologi Anak. Jakarta: CV. Sagung Seto. 2007.

5. Fikawati, Sandra dan Ahmad Syafiq. Kajian Implementasi dan Kebijakan Air Susu lbu Eksklusif dan Inisiasi Menyusui Dini di Indonesia. 2010 (diunduh 28 Oktober 2011). Tersedia dari URL:HYPERLINK http://www.journal.ui.ac.id/upload/artikel/6421299-2-PB.pdf.

6. Anggrita, Kiki. Hubungan Karakterisitk lbu Menyusui Terhadap Pemberian ASI Eksklusif di Wilayah Kerja Puskesmas Medan Amplas Tahun 2009. 2009 (diunduh 28 Oktober 2011). Tersedia dari URL: HYPERLINK http://www.koleksiskripsi.com/2011/05/hbung an-karakteristik-ibu-menyusui.html.

7. Peraturan Pemerintah RI. Peraturan Pemerintah Republik Indonesia Nomor 33 Tahun 2012 tentang Pemberian Air Susu Ibu Eksklusif. 2012 (diunduh 25 Februari 2012). Tersedia dari URL: HYPERLINK http://www.depkes.go.id/downloads/PP\%20A Sl.pdf

8. Kemenkes RI. Profil Kesehatan Indonesia 2010. 2010 (diunduh 3 November 2011) Tersedia dari http //www.depkes.go.id/downloads/PROFIL KES EHATAN INDONESI A 2010.pdf

9. Ismael, Sofyan dan Sudigdo Sastroasmoro. Dasar-Dasar Metodologi Penelitian Klinis, edisi 2. Jakarta: CV. Sagung Seto. 2002.

10. Suyatno. Menghitung Besar Sampel Penelitian Kesehatan Masyarakat. Diunduh 25 Februari 2012. Tersedia dari URL:HYPERLINK http://www.suyatno.blog.undip.ac.id

11. Alwi, Idrus; Siti Setiati; Bambang Setiyohadi Marcellus Simadibrata; Aru W. Sudoyo. Buku Ajar IImu Penyakit Dalam Jilid 1, edisi 5. Jakarta: InternaPublishing. 2009.

12. Roesli, Utami. Mengenal ASI Eksklusif. Jakarta: Niaga Swadaya. 2000.

13. Effendi,Sofian dan Masri Singarimbun Metode Penelitian Survai. Jakarta: Pustaka LP3ES. 2011.

14. Hegar, Badriul dan Magdalena Sahetapy. Air Susu lbu dan Kesehatan Saluran Cerna. 2009 (diunduh 2 November 2011). Tersedia dari URL:HYPERLINK http: //www.idai.or.id/asi/artikel.asp?q=200910291 05942

15. Jackson KM and Nazar AM. Breastfeeding the immune response, and longterm health. J. Am Osteopath Assoc. 2006.

16. Lely. Peran ASI Eksklusif yang Mengandung Antibodi SIgA terhadap Risiko Diare Akut pada Bayi Usia 1-6 Bulan. 2011 (diunduh 25 Februari 2012) Tersedia dari URL:HYPERLINK http: //www.pps.unud.ac.id/disertasi

17. Suradi, Rulina. Manfaat ASI dan Menyusui. Jakarta: Fakultas Kedokteran Universitas Indonesia. 2008.
18. Lamberti, Laura $\mathrm{M}$ et al. breastfeeding and the risk for diarrhea morbidity and mortality. 2011 (diunduh 18 Maret 2012). Tersedia dari URL:HYPERLINK //www.biomedcentral.com/14712458/11/S3/S15

19. Wijayanti, Winda. Hubungan antara Pemberian ASI Eksklusif dengan Angka Kejadian Diare pada Bayi Umur 0-6 Bulan di Puskesmas Gilingan Kecamatan Banjarsari Surakarta. 2010 (diunduh 24 Februari 2012). Tersedia dari URL:HYPERLINK http://www.digilib.uns.ac.id/pengguna.php?m

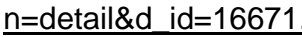

